\title{
Floristic inventory and ecological evaluation of plants of Jani Khel, Bannu, Khyber Pakhtunkhwa, Pakistan
}

\author{
Irfan Ali Shah ${ }^{1}$, Lal Badshah ${ }^{1}$, Tanvir Burni ${ }^{1}$, Noor Ul Uza ${ }^{1 *}$, Abdur \\ Rahman Khan ${ }^{1}$ and Imran Ahmad ${ }^{1,2}$ \\ 1. Department of Botany, University of Peshawar, Pakistan \\ 2. Department of Botany, Shaheed Benazir Bhutto University Sheringal, Upper Dir, Pakistan \\ *Corresponding author's email: noorbotany123@gmail.com \\ Citation \\ Irfan Ali Shah, Lal Badshah, Tanvir Burni, Noor Ul Uza and Imran Ahmad. Floristic inventory and ecological \\ evaluation of plants of Jani Khel, Bannu, Khyber Pakhtunkhwa, Pakistan. Pure and Applied Biology. Vol. 11, Issue \\ 4, pp881-890. http://dx.doi.org/10.19045/bspab.2022.110090
}

\begin{tabular}{llll}
\hline \hline Received: $12 / 11 / 2021$ & Revised: 13/01/2022 & Accepted: 28/01/2022 & Online First: 04/02/2022
\end{tabular}

\section{Abstract}

Ethnobotanical study aids in the discovery of novel pharmaceuticals for the treatment of various ailments in scientific times. Local people have gathered ethnobotanic information through a hitand-run manner from millennia of indigenous wisdom and passed it down from generation to generation. This knowledge serves as a foundation for scientifically investigating a plant's potential medicinal effects. It will also provide a baseline for researchers in the various field of plant sciences. The current study was conducted during 2015-16 to record the floristic composition and ecological characteristics of the flora of Jani Khel, district Bannu. The floral composition revealed 80 species belonging to 29 families. Among them, 27 families were dicotyledons and 02 were monocotyledons. Papilionaceae and Poaceae were the leading families each with 08 species followed by Asteraceae and Cucurbitaceae (07 species each), Umbelliferae (06 species), Brassicaceae and Chenopodiaceae (05 species each), Mimosaceae, Moraceae and Solanaceae (04 species each), Alliaceae, Euphorbiaceae, Plantaginaceae and Rhamnaceae were represented by 2 species each, while the remaining families comprised single species. Therophytes (48 species, $60 \%$ ) was the dominant life form, followed by Microphanerophytes (10 species, $12.5 \%$, Hemicryptophytes (08 species, 10\%), Chamaephytes (07 species, 8.75\%), Nanophanerophytes (04 species, 5\%) and Geophytes (03 species, 3.75\%). Nanophylls with (27 species, 33.75\%) and Microphylls (20 species, 25\%) were dominant leaf size classes. Megaphylls and Aphyllous were considered the least infrequent leaf size spectra in the area. It was observed that the research area has a diversity of plants, but due to anthrapogenic activities the flora is under pressure. So, measures should be taken to conserve the flora.

Keywords: Bannu; Ecological characteristics; Floristic composition; Jani Khel

\section{Introduction}

Jani Khel, Bannu is located between $32^{\circ} 69^{\prime} 79.66$ and $32^{\circ} 87^{\prime} 78.31$ North latitudes and $70^{\circ} 36^{\prime} 01.90$ and $70^{\circ} 54^{\prime} 00.54$ East longitudes. It is surrounded on the West by the District North Waziristan, on the East by District Lakki Marwat, on the North by District Bannu (Tehsil Miryan), and on the 
South by South Waziristan (Fig. 1). It has total area of 745 square $\mathrm{km}$. The area has a unique phytodiversity of sub-tropical vegetation. The area has four seasons such as winter (mid of November to February) with temperature ranges from $5^{\circ} \mathrm{C}$ to $26^{\circ} \mathrm{C}$, spring
(March to mid of April), Summer (mid of April to end of August) and Autumn (September to end of October). The average precipitation is about $66.8 \mathrm{~mm}$, in which maximum rain fall occurs in the months of July and August.

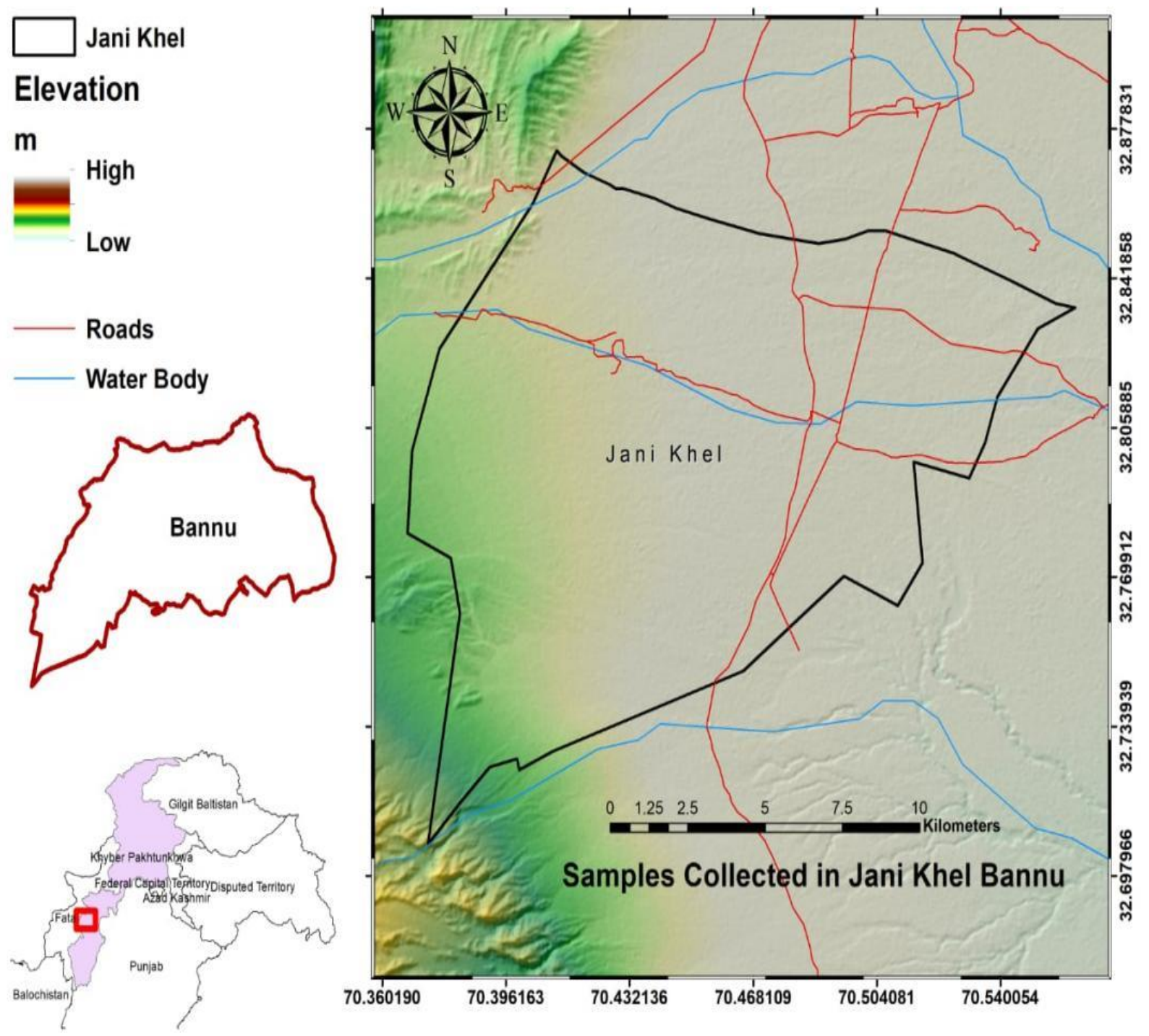

\section{Figure 1. Map of the research area}

The word flora refers to the total number of species in particular region and vegetation refers to their distribution and assemblage [1]. Flora is a complete checklist of plant species growing in any geographical area either wild or cultivated. The floristic composition of region is affected by agriculture practices, overgrazing, deforestation, and natural disasters [2,3]. 
Biological spectrum reflects the physiognomy of the flora as a result of all processes in relation with environment [4, 5]. This helps in understanding the ecological elucidation of vegetation. Classification based on life form is more reliable because it based on the position and degree of parenting bud [6]. Life form study is an important part of the flora description [7]. Similarly, leaf size classes play a significant role in physiological processes [8]. The structure of leaf usually determines the habitat condition such as microphyll leaves represent the dry and hot environmental condition [9]. The knowledge of leaf size classes might be helpful for the study of physiological processes of plants [10].

Jani Khel, Bannu is semi-arid area with and its flora faces the harsh environmental condition. The main aim of this study was to enlist the flora and ecological characteristics of the research area.

\section{Materials and Methods Floristic Composition}

To prepare a complete floristic list of plants, specimens were collected in different seasons during 2015-2016 from different parts of Jani Khel, Bannu. The specimens were collected, preserved and mounted on standard size herbarium sheets, and then identified with the flora of Pakistan [11, 12]. Voucher numbers were allotted to specimens and the other descriptions were written on each sheet accordingly. The identified specimens were submitted to the herbarium of Botany Department, University of Peshawar.

\section{Biological Spectrum}

Life form classes of the plants were determined with standard method of [6], such as Geophytes, Nanophanerophytes, Microphanerophytes, Chamaephytes, Hemicryptophytes and Therophytes.

For estimation of leaf size in the field, [6] diagram was used. Based on leaf size spectrum, the plants were divided into five classes such as Megaphyll, Mesophyll, Mirophyll, Leptophyll, Nanophyll and Aphyllous.

\section{Results and Discussion}

Floristic composition and ecological characteristics

The flora of Jani Khel, Bannu consisted of 80 species of 29 families (Plate 1 \& Fig. 2). Dicotyledons were represented by 27 families and monocotyledons by 02 families. Papilionaceae and Poaceae were the leading families in terms of species composition $(8$ species each) followed by Asteraceae and Cucurbitaceae (7 species each), Umbelliferae (6 species), Brassicaceae and Chenopodiaceae (5 species each), Mimosaceae, Moraceae, and Solanaceae (4 species each), Alliaceae, Euphorbiaceae, Plantaginaceae and Rhamnaceae (2 species each) as shown in (Table 1). Habit of the flora dominated by herbs (62\%) followed by trees $(18 \%)$ and shrubs $(11 \%)$ and climbers $(9 \%)$ as shown in (Fig. 3). Close to our finding, [13] reported flora of Bannu which comprised 193 plant species of belonging 54 families. Of the species, 145 species $(75.13 \%)$ were dicots and 48 species $(24.87 \%)$ were monocots. Family Poaceae was dominant with 37 species. Similarly, [2] reported Poaceae (34 species), Papilionaceae (19 species) Asteraceae (14 species), Chenopodiaceae (10 species) and Brassicaceae (9 species) as dominant plants families from District Tank. [14] recorded that Poaceae is the leading family from OleaAcacia forest of District Karak. [15] recorded Poaceae (12 species), Papilionaceae (07 species), and Asteraceae (06 species) representative families of angiosperms plants from Dureji Gam reserve which are in agreement with our findings. [16, 17] also strongly supported our results. 

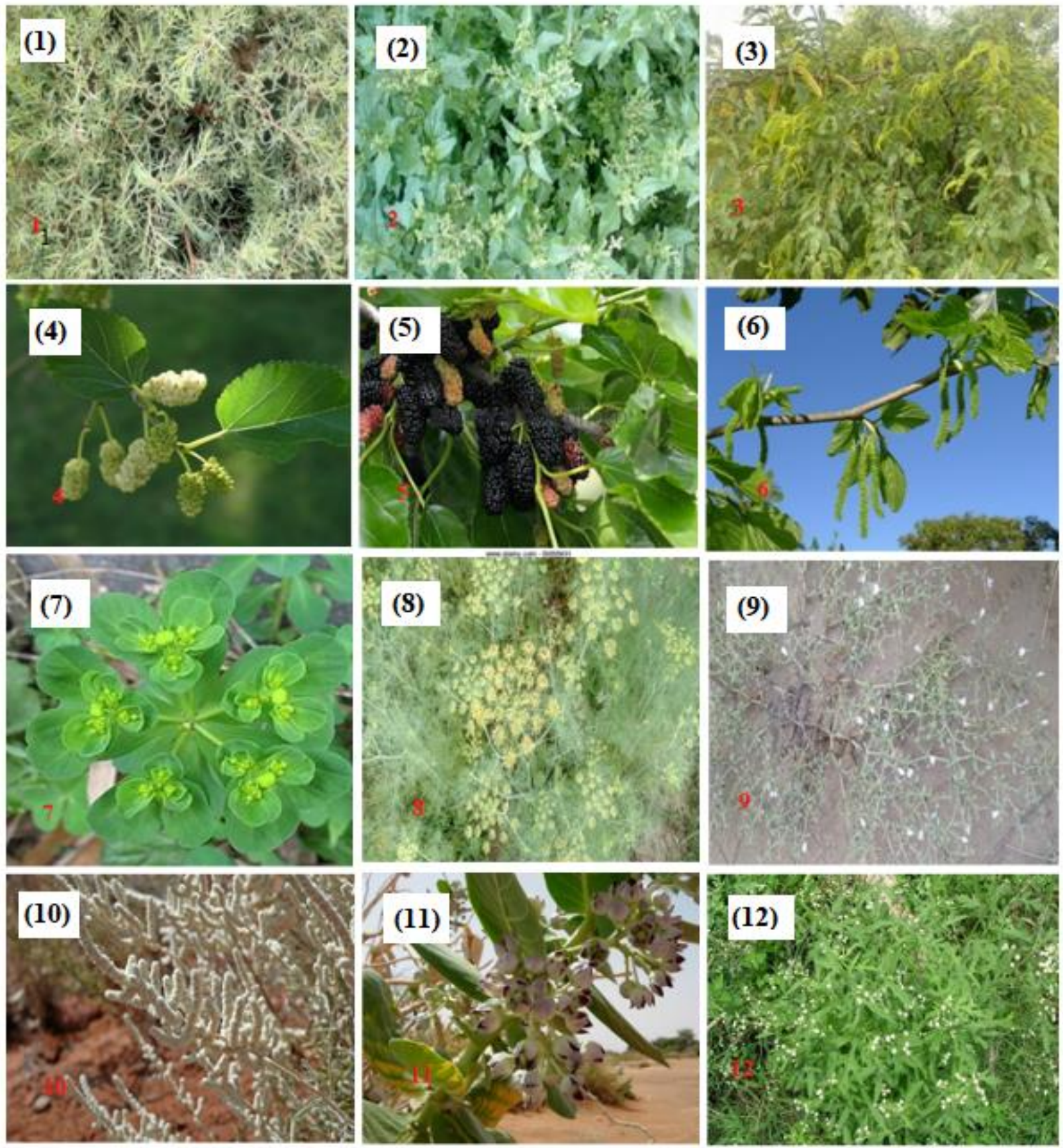

Plate 1. Sueada fructicosa 2. Chenopodium albam 3. Acacia modesta 4. Morus alba 5. M. nigra 6. Morus laevigata 7. Euphorbia heliscopia 8. Anethum sowa 9. Fagonia indica 10. Arva javanica 11. Calotropis procera 12. Parthenium hysterophorus 


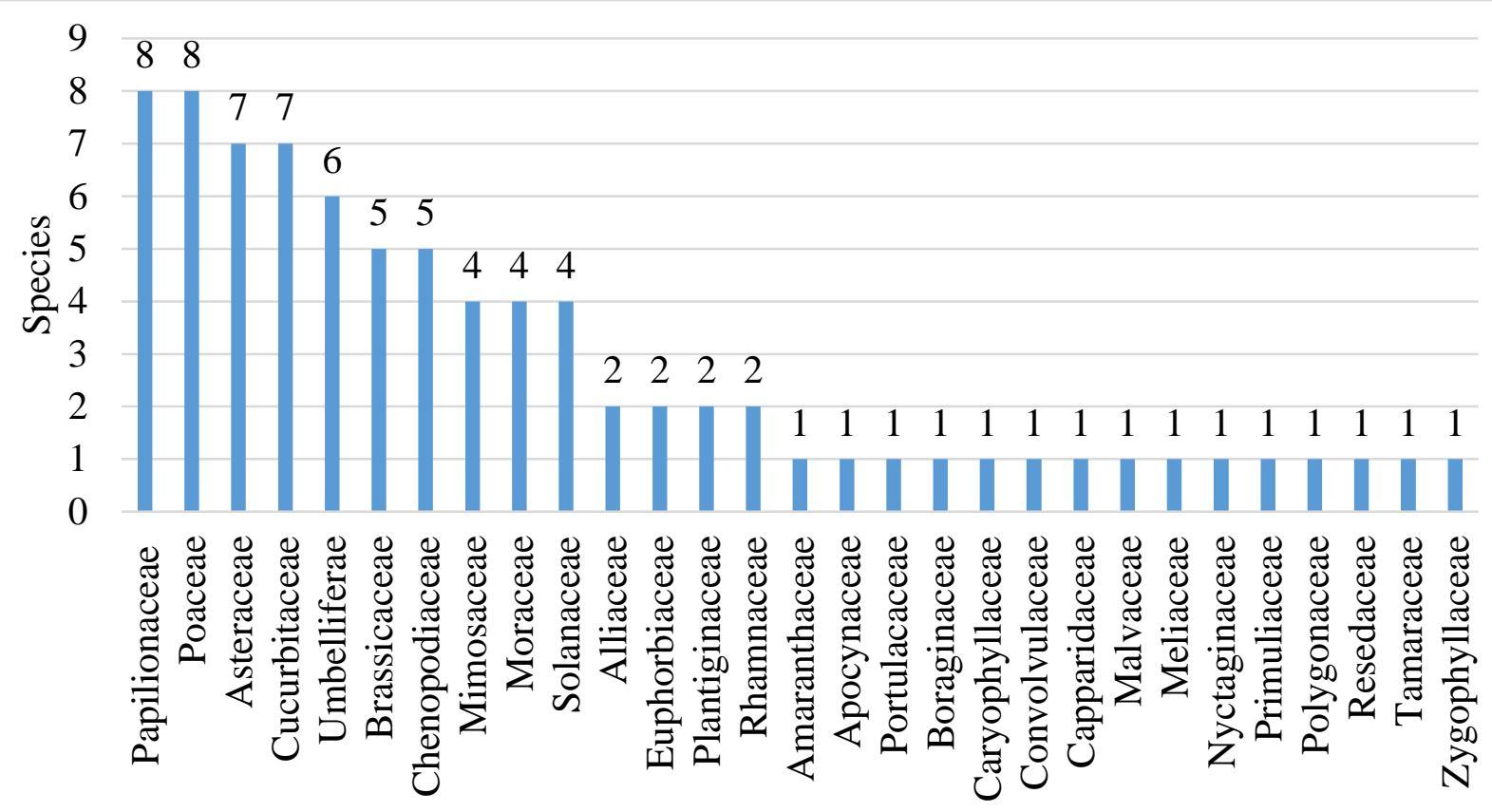

Famliies

Figure 2. Species distribution in the families

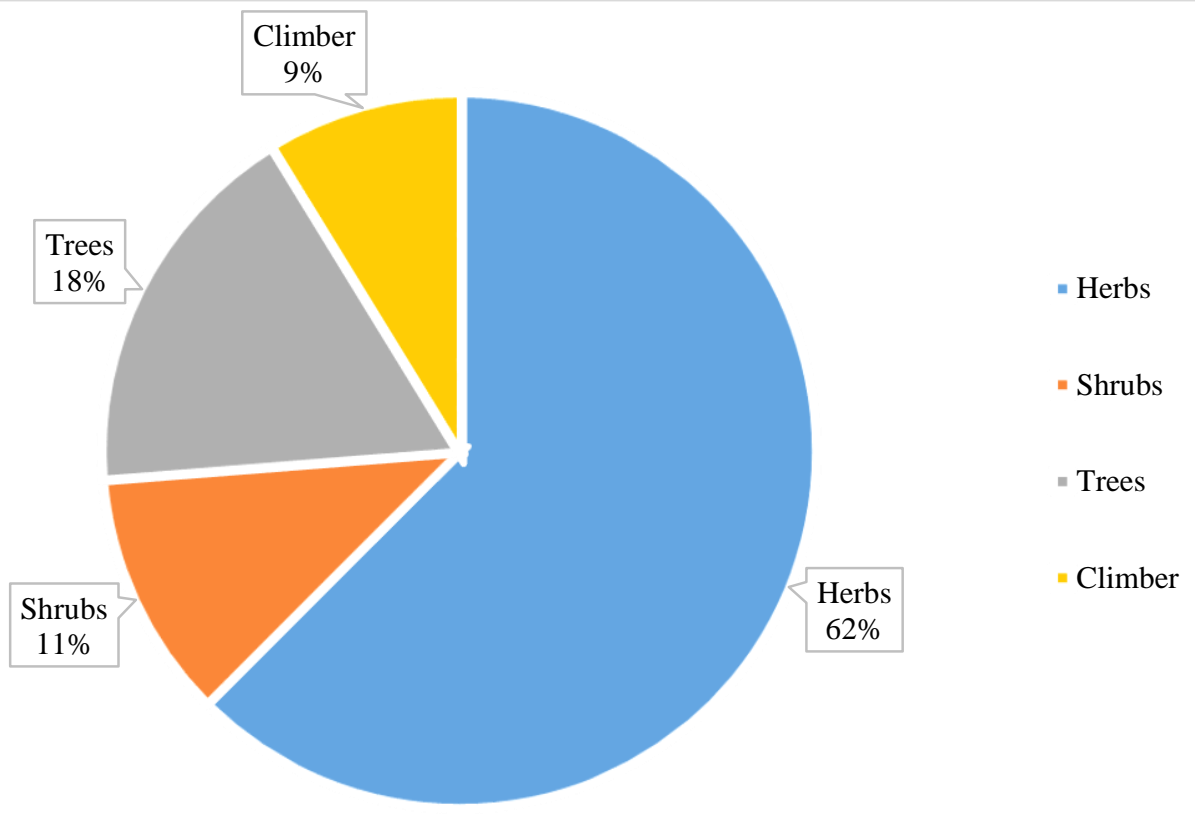

Figure 3. Habit of the species 
Table 1. Floristic composition, Life form and Leaf size spectrum of flora of Jani Khel, Bannu

\begin{tabular}{|c|c|c|c|c|c|c|}
\hline $\begin{array}{l}\text { S. } \\
\#\end{array}$ & Species name & Voucher number & Family & Habit & $\begin{array}{l}\text { Life } \\
\text { form }\end{array}$ & $\begin{array}{l}\text { Leaf } \\
\text { size }\end{array}$ \\
\hline 1 & Allium cepa $\mathrm{L}$. & Shah.Bot.01(UOP) & Alliaceae & $\mathrm{H}$ & Geo & Nan \\
\hline 2 & A. sativum $\mathrm{L}$. & Shah.Bot.02(UOP) & & $\mathrm{H}$ & Geo & Nan \\
\hline 3 & Polypogon monspeliensis (L) D.f. & Shah.Bot.03(UOP) & Poaceae & $\mathrm{H}$ & The & Mic \\
\hline 4 & Avena fatua $\mathrm{L}$. & Shah.Bot.04(UOP) & & $\mathrm{H}$ & The & Mic \\
\hline 5 & Cymbopogon jawarancusa (Jones)Schlt & Shah.Bot.05(UOP) & & $\mathrm{H}$ & The & Mic \\
\hline 6 & Eragrostis minor Host & Shah.Bot.06(UOP) & & $\mathrm{H}$ & Hem & Nan \\
\hline 7 & Hordeum vulgare $\mathrm{L}$. & Shah.Bot.07(UOP) & & $\mathrm{H}$ & The & Mic \\
\hline 8 & Triticum aestivum $\mathrm{L}$. & Shah.Bot.08(UOP) & & $\mathrm{H}$ & The & Mic \\
\hline 9 & Zea mays L. & Shah.Bot.09(UOP) & & $\mathrm{H}$ & The & Mes \\
\hline 10 & Oryza sativa $\mathrm{L}$ & Shah.Bot.10(UOP) & & $\mathrm{H}$ & The & Mic \\
\hline 11 & Aerva javanica (Burm.f) Juss, ex Schult. & Shah.Bot.11(UOP) & Amaranthaceae & $\mathrm{H}$ & Cha & Lep \\
\hline 12 & Calotropis procera Willd & Shah.Bot.12(UOP) & Apocynaceae & $\mathrm{S}$ & Cha & Mes \\
\hline 13 & Portulaca oleracea L. & Shah.Bot.13(UOP) & Portulacaceae & $\mathrm{H}$ & The & Nan \\
\hline 14 & Parthenium hysterophorus L. & Shah.Bot.14(UOP) & Asteraceae & $\mathrm{H}$ & The & Mes \\
\hline 15 & Scorzonera lacinata L. & Shah.Bot.15(UOP) & & $\mathrm{H}$ & Geo & Mic \\
\hline 16 & Calendula arvensis $\mathrm{L}$. & Shah.Bot.16(UOP) & & $\mathrm{H}$ & The & Nan \\
\hline 17 & Filago pyramidata $\mathrm{L}$. & Shah.Bot.17(UOP) & & $\mathrm{H}$ & The & Lep \\
\hline 18 & Conzya Canadensis (L.) Cronquist & Shah.Bot.18(UOP) & & $\mathrm{H}$ & The & Lep \\
\hline 19 & Cirsium arvensis (L.) Scop. & Shah.Bot.19(UOP) & & $\mathrm{H}$ & The & Mic \\
\hline 20 & Carthamus oxycantha M.Bieb & Shah.Bot.20(UOP) & & $\mathrm{H}$ & The & Mic \\
\hline 21 & Heliotropium europaeum L. & Shah.Bot.21(UOP) & Boraginaceae & $\mathrm{H}$ & The & Mic \\
\hline 22 & Brassica rapa $\mathrm{L}$. & Shah.Bot.22(UOP) & Brassicaceae & $\mathrm{H}$ & The & Nan \\
\hline 23 & Malcolmia cabulica $\mathrm{L}$. & Shah.Bot.23(UOP) & & $\mathrm{H}$ & The & Mic \\
\hline 24 & Eruca sativa Mill & Shah.Bot.24(UOP) & & $\mathrm{H}$ & The & Nan \\
\hline 25 & Malcolmia africana (L.) R Br. & Shah.Bot.25(UOP) & & $\mathrm{H}$ & The & Nan \\
\hline 26 & Farsetia jacquemontii Hook.f.\&thoms & Shah.Bot.26(UOP) & & $\mathrm{H}$ & The & Nan \\
\hline 27 & Spinacia oleracea $\mathrm{L}$. & Shah.Bot.27(UOP) & Chenopodiaceae & $\mathrm{H}$ & The & Mic \\
\hline 28 & Sueada fructicosa Forssk.ex J.F.Gmelin & Shah.Bot.28(UOP) & & $\mathrm{S}$ & Cha & Lep \\
\hline 29 & Salsola fetid Delile. & Shah.Bot.29(UOP) & & $S$ & Cha & Lep \\
\hline 30 & Chenopodium Album L. & Shah.Bot.30(UOP) & & $\mathrm{H}$ & The & Nan \\
\hline 31 & C. murale $\mathrm{L}$. & Shah.Bot.31(UOP) & & $\mathrm{H}$ & The & Lep \\
\hline 32 & Cucumis sativus L. & Shah.Bot.32(UOP) & Cucurbitaceae & $\mathrm{C}$ & The & Mic \\
\hline 33 & Cucurbita pepo L. & Shah.Bot.33(UOP) & & $\mathrm{C}$ & The & Mes \\
\hline 34 & C. maxima Duchesne & Shah.Bot.34(UOP) & & $\mathrm{C}$ & The & Meg \\
\hline 35 & Luffa acutangula (L.) Roxb. & Shah.Bot.35(UOP) & & $\mathrm{C}$ & The & Mac \\
\hline 36 & L. cylindrica $\mathrm{L}$. & Shah.Bot.36(UOP) & & $\mathrm{C}$ & The & Mac \\
\hline 37 & Momordica charantia $\mathrm{L}$. & Shah.Bot.37(UOP) & & $\mathrm{C}$ & The & Mes \\
\hline 38 & Spergula arvensis $\mathrm{L}$. & Shah.Bot.38(UOP) & Caryophyllaceae & $\mathrm{H}$ & $\mathrm{He}$ & Nan \\
\hline 39 & Convolvulus arvensis $\mathrm{L}$. & Shah.Bot.39(UOP) & Convolvulaceae & $\mathrm{H}$ & The & Nan \\
\hline 40 & Euphorbia heliscopa L. & Shah.Bot.40(UOP) & Euphorbiaceae & $\mathrm{H}$ & The & Nan \\
\hline 41 & Ricinis communis $L$ & Shah.Bot.41(UOP) & & $\mathrm{S}$ & Cha & Mes \\
\hline 42 & Capparis deciduas Forssk Edgew & Shah.Bot.42(UOP) & Capparidaceae & $\mathrm{T}$ & Nanp & Aph \\
\hline 43 & Malva neglecta wallr. & Shah.Bot.43(UOP) & Malvaceae & $S$ & The & Mic \\
\hline 44 & Melia azadarach $\mathrm{L}$. & Shah.Bot.44(UOP) & Meliaceae & $\mathrm{T}$ & Micp & Nan \\
\hline 45 & Acacia nilotica (L.) Delile & Shah.Bot.45(UOP) & Mimosaceae & $\mathrm{T}$ & Micp & Lep \\
\hline 46 & A. modesta wall & Shah.Bot.46(UOP) & & $\mathrm{T}$ & Micp & Lep \\
\hline 47 & Albizia lebbeck L. & Shah.Bot.47(UOP) & & $\mathrm{T}$ & Micp & Lep \\
\hline 48 & Prosopis juliflora swarts & Shah.Bot.48(UOP) & & $\mathrm{T}$ & Nanp & Lep \\
\hline 49 & Morus alba L. & Shah.Bot.49(UOP) & Moraceae & $\mathrm{T}$ & Micp & Mes \\
\hline
\end{tabular}




\begin{tabular}{|c|c|c|c|c|c|c|}
\hline 50 & M. laevigata $\mathrm{Wal} . \mathrm{exBrandis.}$ & Shah.Bot.50(UOP) & & $\mathrm{T}$ & Micp & Mic \\
\hline 51 & M. nigra $\mathrm{L}$. & Shah.Bot.51(UOP) & & $\mathrm{T}$ & Micp & Mes \\
\hline 52 & Ficus religiosa $\mathrm{L}$. & Shah.Bot.52(UOP) & & $\bar{T}$ & Nanp & Mes \\
\hline 53 & Boerhavia procera $\mathrm{L}$. & Shah.Bot.53(UOP) & Nyctaginaceae & $\mathrm{H}$ & Hem & Nan \\
\hline 54 & Medicago polymorpha $\mathrm{L}$. & Shah.Bot.54(UOP) & Papillionaceae & $\mathrm{H}$ & The & Nan \\
\hline 55 & M. minima (L.) Grufb & Shah.Bot.55(UOP) & & $\mathrm{H}$ & The & Nan \\
\hline 56 & Dalbergia sissoo Roxb & Shah.Bot.56(UOP) & & $\mathrm{T}$ & Micp & Nan \\
\hline 57 & Astragalus hamosus L. & Shah.Bot.57(UOP) & & $\mathrm{H}$ & Cha & Lep \\
\hline 58 & Argyrolobium roseum L. & Shah.Bot.58(UOP) & & $\mathrm{H}$ & The & Nan \\
\hline 59 & Cicer ariethenum $\mathrm{L}$. & Shah.Bot.59(UOP) & & $\mathrm{H}$ & The & Lep \\
\hline 60 & Alhagi maurorum Medik & Shah.Bot.60(UOP) & & $\mathrm{S}$ & Hem & Lep \\
\hline 61 & Vicia sativa $\mathrm{L}$. & Shah.Bot.61(UOP) & & $\mathrm{C}$ & The & Mic \\
\hline 62 & Anagallis arvensis $\mathrm{L}$. & Shah.Bot.62(UOP) & Primuliaceae & $\mathrm{H}$ & The & Nan \\
\hline 63 & Plantago ciliate (Boiss) Rech & Shah.Bot.63(UOP) & Plantaginaceae & $\mathrm{H}$ & The & Nan \\
\hline 64 & $P$. lanceolata $\mathrm{L}$. & Shah.Bot.64(UOP) & & $\mathrm{H}$ & Hem & Mes \\
\hline 65 & Rumex dentatus $\mathrm{L}$. & Shah.Bot.65(UOP) & Polygonaceae & $\mathrm{H}$ & The & Mes \\
\hline 66 & $\begin{array}{c}\text { Oligomeris linifolia (Vahl. Ex Hornem.) } \\
\text { J. F. Macbr. }\end{array}$ & Shah.Bot.66(UOP) & Resedaceae & $\mathrm{H}$ & The & Nan \\
\hline 67 & Ziziphus nummularia (Burm.f.) & Shah.Bot.67(UOP) & Rhamnaceae & $\mathrm{T}$ & Nanp & Nan \\
\hline 68 & Z. mauritina Lam. & Shah.Bot.68(UOP) & & $\mathrm{T}$ & Micp & Nan \\
\hline 69 & Capsicum Аппиит L. & Shah.Bot.69(UOP) & Solanaceae & $\mathrm{H}$ & The & Nan \\
\hline 70 & Withania coagulans (Stocks) Dunal & Shah.Bot.70(UOP) & & $\mathrm{S}$ & Cha & Mic \\
\hline 71 & Solunum surattense Burm. f. & Shah.Bot.71(UOP) & & $\mathrm{H}$ & Hem & Mic \\
\hline 72 & Datura alba Nees & Shah.Bot.72(UOP) & & $\mathrm{S}$ & The & Mic \\
\hline 73 & Tamarixa phylla (L.) karst & Shah.Bot.73(UOP) & Tamaraceae & $\mathrm{T}$ & Micp & Lep \\
\hline 74 & Anethum sowa Roxb..ex Fleming & Shah.Bot.74(UOP) & Umbelliferae & $\mathrm{H}$ & The & Lep \\
\hline 75 & Foeniculum vulgare Mill. & Shah.Bot.75(UOP) & & $\mathrm{H}$ & The & Lep \\
\hline 76 & Coriandrum sativum L. & Shah.Bot.76(UOP) & & $\mathrm{H}$ & Hem & Nan \\
\hline 77 & Trachyspermum ammi L. & Shah.Bot.77(UOP) & & $\mathrm{H}$ & The & Lep \\
\hline 78 & Ammi visnaga (L.) lam & Shah.Bot.78(UOP) & & $\mathrm{H}$ & The & Lep \\
\hline 79 & Torilis leptophylla (L.) Rchb.f. & Shah.Bot.79(UOP) & & $\mathrm{H}$ & The & Nan \\
\hline 80 & Fagonia indica Burm.f. & Shah.Bot.80(UOP) & Zygophyllaceae & $\mathrm{S}$ & The & Lep \\
\hline
\end{tabular}

KEY: Habit: H-Herb, S-Shrub, T-Tree, C-Climber; Life form: Cha-Chamaephytes, Geo-Geophytes, HemHemicryptophytes, Micp-Microphanerophytes, Nanp-Nanophanerophytes, The-Therophytes; Leaf Size: AphAphylloues, Lep-Leptophyll, Mac-Macrophyll, Meg-Megaphyll, Mes-Mesophyll, Mic-Microphyll, Nan-Nanophyll

\section{Life form}

The observed life form of the plants was dominated by Therophytes with 48 species (60\%) followed by Microphanerophytes with 10 species (12.5\%), Hemicryptophytes with 08 species (10\%), Chamaephytes with 07 species $(8.75 \%)$, Nanophanerophytes with 04 species $(5 \%)$ and Geophytes with 03 species $(3.75 \%)$ as shown in (Table 2 \& Fig. 4). [6] recognized three phytoclimate on the earth. Phanerophytic climate which lies in tropics, Therophytic climate which lies in deserts and Hemicryptophytes which include greater parts of the cold temperate zone. In the present study, dominance of Therophytes life form is due to the abiotic factors like high temperature and drought, and biotic influence like extensive agriculture practice, deforestation, grazing and trampling. Close to our finding, [13] studied recorded Therophytes (60.62\%) and Hemicryptophytes $(09.84 \%)$ the dominant life form classes from District Bannu. Similarly, [18] reported Therophytes (16 species, $29.6 \%$ ) and Megaphanerophytes (14 species, $25.9 \%$ ) dominant life forms from Dara Adam Khel. [2] studied the flora of District Tank and recorded Therophytes and Hemicryptophytes the leading life form classes. [18] studied the biological spectrum 
and found Therophyte dominant life form in their research area. [19] observed Therophytes and Phanerophytes the leading plant life form of Khanpur Dam, Khyber Pakhtunkhwa, Pakistan which is comparable with our findings. [20] observed that therophytes (234 species, 26.97\%) and hemicryptophytes (154 species, 26.97\%) are the characteristic life form of the flora of District Chitral, which was additionally in agreement to our results.

\section{Leaf size spectrum}

Leaf size spectrum of Jani Khel demonstrated Nanophylls $33.75 \%$ (27 species, 33.75\%), followed by Microphylls 25\% (20 species), Leptophylls 22.5\% (18 species), Mesophylls $13.75 \%$ (11 species), Macrophylls 2.5\% (02 species) and Megaphylls and Aphlyllous $1.5 \%$ (01 species) of each as shown in (Table 2 \& Fig. 5). Leaf size spectrum of plants reveled that Nanophylls, Microphylls and Leptophylls are characteristic of hot and dry habitat vegetation $[21,22]$. This study shows that the weather condition of Jani Khel is hot and dry that supports the Nanophylls and Microphylls leaf sizes. [13] declared Nanophylls $48.18 \%$ (93 species) and Leptophylls $21.24 \%$ (41 species) are the dominant leaf size classes in District Bannu, which explained our outcomes. Similarly, [16] explored leaf size spectra of the plants of Sheikh Malton, Mardan that comprised of Microphyll (46.2\%), Mesophyll (25.3\%) and Nanophylls $(25.3 \%)$ which are close to the current findings. The study of [2] declared the leaf size of District Tank, comprised of $46.8 \%$ (96 species) Nanophylls, and Leptophylls $27.8 \%$ (57 species) which also strengthened our results.

Table 2. Percentage distribution of life form and leaf spectra of flora

\begin{tabular}{|c|c|c|c|}
\hline S\# & A. Life Form & No. of species & \% age of species \\
\hline 1. & Therophytes & 48 & $60 \%$ \\
\hline 2. & Hemicryptophytes & 08 & $10 \%$ \\
\hline 3. & Chamaephytes & 07 & $8.75 \%$ \\
\hline 4. & Geophytes & 03 & $3.75 \%$ \\
\hline 5. & Nanophanerophytes & 04 & $5 \%$ \\
\hline 6. & Microphanerophytes & 10 & $12.5 \%$ \\
\hline & Total & $\mathbf{8 0}$ & $\mathbf{1 0 0}$ \\
\cline { 2 - 4 } & B. Leaf size & No. of species & \% age of species \\
\hline 1. & Leptophyll & 18 & $22.5 \%$ \\
\hline 2. & Nanophyll & 27 & $33.75 \%$ \\
\hline 3. & Microphyll & 20 & $25 \%$ \\
\hline 4. & Macrophyll & 02 & $2.5 \%$ \\
\hline 5. & Mesophyll & 11 & $13.5 \%$ \\
\hline 6. & Megaphyll & 01 & $1.25 \%$ \\
\hline 7. & Aphyllous & 01 & $1.25 \%$ \\
\hline & Total & $\mathbf{8 0}$ & $\mathbf{1 0 0}$ \\
\hline
\end{tabular}




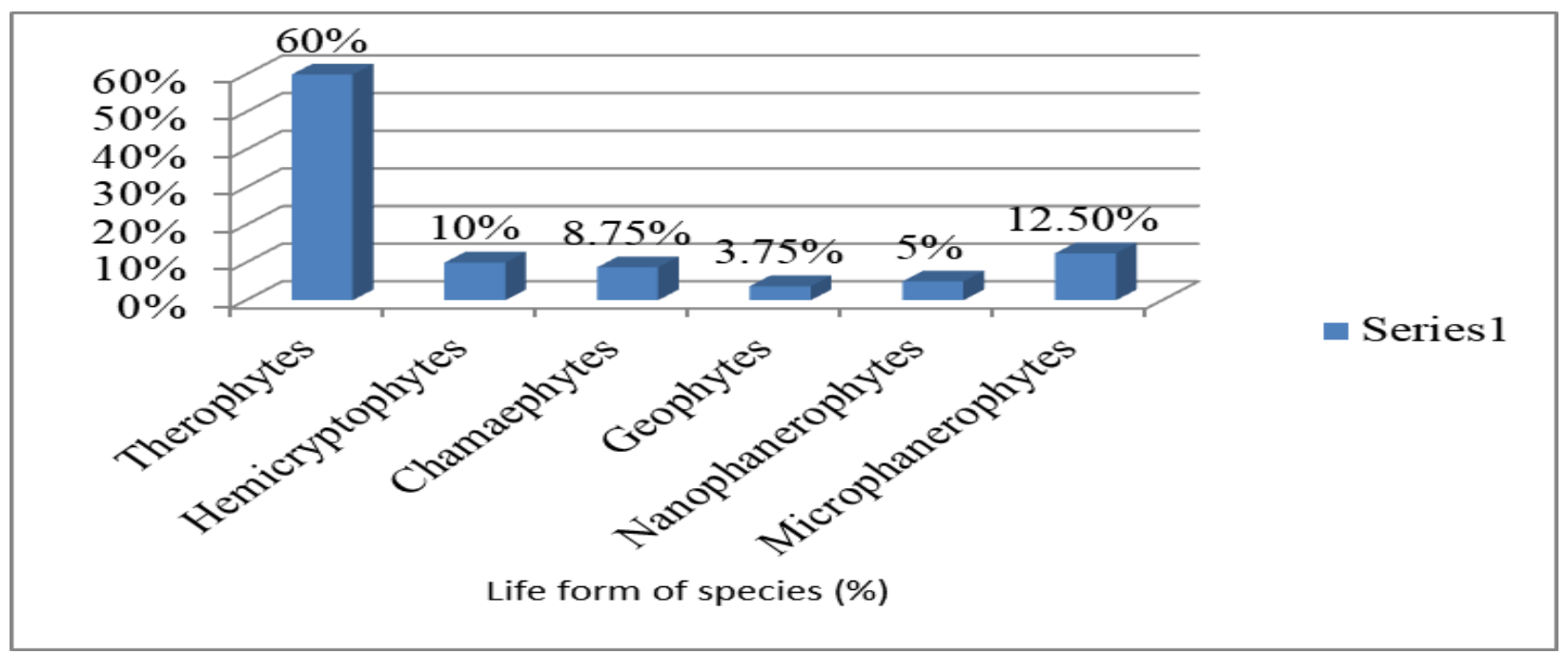

Figure 4. \% Life form of flora of Jani Khel, Bannu

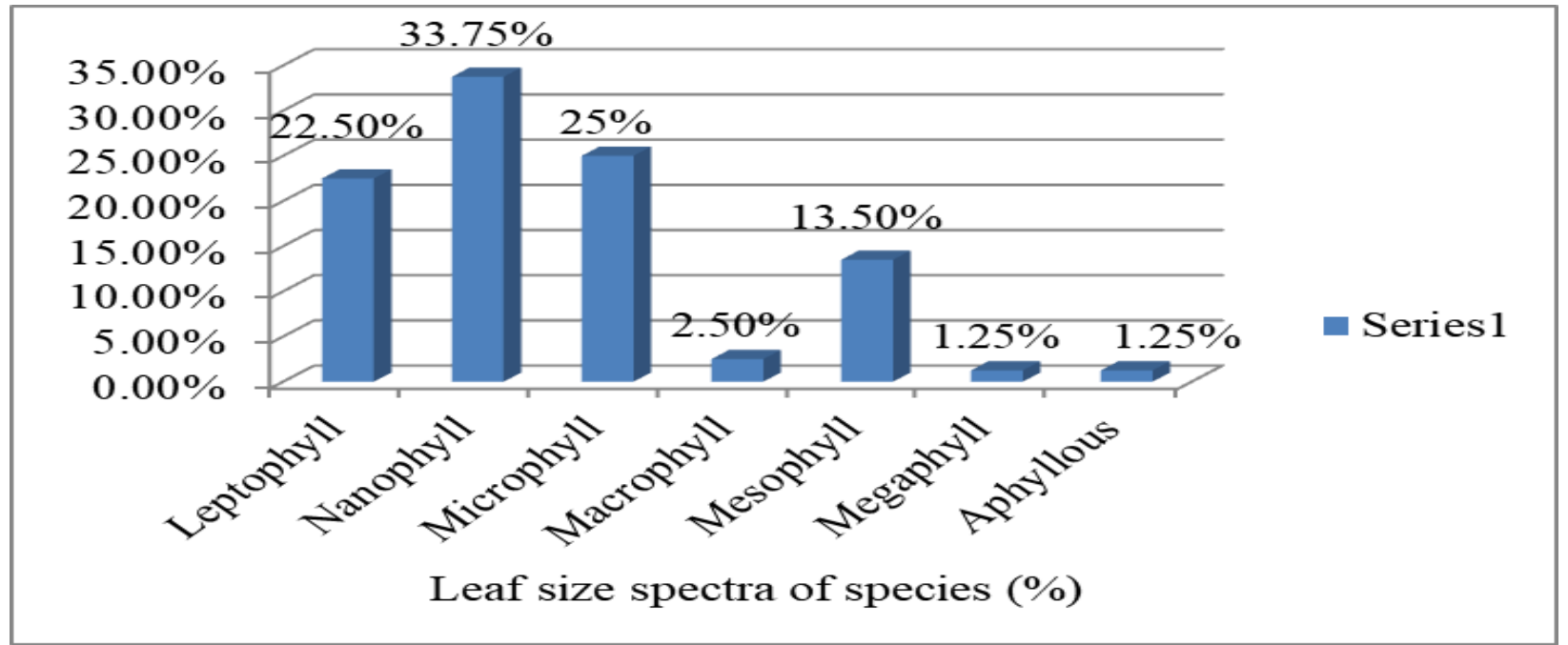

Figure 5. \% Leaf size of flora of Jani Khel, Bannu

\section{Conclusion and Recommendations}

The flora of Jani Khel, Bannu consisted of 80 plants species belonging to 29 families. Papilionaceae, Poaceae, Asteraceae, Umbelliferae, Chenopodiaceae were the most prevalent families. The climatic condition of the area is dry and hot which supports Therophyte and Microphyllous classes of biological spectrum. The current study believed that many species have been left unrecorded, so a long-term comprehensive study needed to document it.

Authors' Contributions

Conceived and designed the experiments: $\mathrm{T}$ Burni \& L Badshah, Performed the experiments: IA Shah, Contributed materials: T Burni, L Badshah, AR Khan \& I Ahmad, Wrote the paper: NU Uza \& IA Shah.

\section{References}

1. Ali A, Badshah L \& Hussain F (2016). Floristic composition and Ecological characteristics of Chail Valley, District Swat, Pakistan. Pak J Bot 48(3): 10131026.

2. Badshah L, Hussain F \& Sher Z (2013). Floristic inventory, Ecological characteristics and biological spectrum of rangeland, District Tank, Pakistan. Pak J Bot 45(4): 1159-1168. 
3. Shah M \& Rozina (2013). Phytosociological attributes and Phytodiversity of Dheri Baba Hill and Peer Taab Graveyard, district Swabi, Khyber Pakhtunkhwa, Pakistan. PJLS 1(1): 1-6.

4. Khan M, Hussain F, Musharaf S \& Imdadullah S (2011). Floristic composition, life form and leaf size spectra of the coal mine area vegetation of Darra Adam Khel, Khyber Pakhtunkhwa, Pakistan. J Biol Environ Sci 1(3): 1-6.

5. Traiser C, Klotz S, Uhl D \& Mosbrugger V (2005). Environmental signals from leaves-a physiognomic analysis of European vegetation. New Phytol 166(2): 465-484.

6. Raunkiær C (1934). The Life Forms of Plants and Statistical Plants Geography being the collected Papers of C. Raunkiaer. Clarendon press, Oxford.

7. Hussain A, Mirza SN, Khan IA \& Naeem MA (2009). Determination of relative species composition and seasonal plant communities of Nurpur reserved forest in scrub rangelands of District Chakwal. Pak J Agri Sci 46(1): 55-59.

8. Yates MJ, Verboom GA, Rebelo AG \& Cramer MD (2010). Eco-physiological significance of leaf size variation in Proteaceae from the Cape Floristic Region. Function Ecol 24(3): 485-492.

9. Khan W, Khan SM, Ahmad H, Alqarawi AA, Shah GM, Hussain M \& Abd_Allah (2018). Life forms, leaf size spectra, regeneration capacity and diversity of plant species grown in the Thandiani forests, District Abbottabad, Khyber Pakhtunkhwa, Pakistan. Saudi J Biol Sci 25(1): 94-100.

10. Oosting HJ (1956). The Study of Plant Communities, 2nd edition, pp: 69-78. W.H. Freeman and Co., Sanfrancisco.

11. Ali SI \& Qaisa M (1995-2010). Flora of Pakistan. Pakistan Agricultural Research Council, Islamabad.

12. Nasir E \& Ali SI (1971-2007). Flora of West Pakistan Department of Botany, University of Karachi, Karachi, Pakistan.
13. Ihsan U, Din SU, Ullah F, Khan SU, Khan A, Khan RA \& Shah Z (2016). Floristic composition, ecological characteristics and biological spectrum of District Bannu, Khyber Pakhtunkhawa, Pakistan. J Human Ecol 54(1):1-11.

14. Naveed S, Hussain F, Khattak I, \& Badshah L (2012). Floristic Composition and Ecological Characteristics of Olea-Acacia Forest of Shamshokii District Karak. Global J Sci Front Res 12(8): 31-6.

15. Perveen A, Sarwar GR \& Hussain I (2008). Plant biodiversity and phytosociological attributes of Dureji (Khirthar Range). PakJ Bot 40(1): 17-24.

16. Khan M, Hussain F \& Musharaf S (2013). Floristic composition and biological characteristics of the vegetation of Sheikh Maltoon Town District Mardan, Pakistan. Annual Res Rev Bio 31-41.

17. Qureshi R (2008). Vegetation assessment of Sawan Wari of Nara desert, Pakistan. Pak J Bot 40(5): 1885-1895.

18. Khan M, Hussain F \& and Musharaf S (2014). Floristic composition and ecological characteristics of Shahbaz Garhi, District Mardan, Pakistan. Global J Sci Front Res 14(1): 7-17.

19. Qureshi R, Shaheen H, Ahmed MI \& Munir M (2014). Phytodiversity and plant life of Khanpur Dam, Khyber Pakhtunkhwa, Pakistan. Pak J Bot 46(3): 841-849.

20. Hussain F, Shah M, Badshah L \& Durani JL (2015). Diversity and ecological characteristics of Flora of Mastuj Valley, Distric Chitral, Pakistan. Pak J Bot 47(2): 415-510.

21. Cain SA \& G.M. De Oliveria Castro (1959). Manual of Vegetation Analysis. Harper \& Brothers, New York.

22. Tareen RB, \& Qadir SA (1993). Life form and Leaf size spectra of the plant communities of diverse areas ranging from Harnai, Sinjawi to Duki regions of Pakistan. Pak J Bot 25 (1): 83-92. 